\title{
EQUILIBRIUM MOISTURE CONTENT FOR TWO PEANUT VARIETIES
}

\section{Ghanem T.H. M. El-Said Shetawy S.H. Mohamed Desoky \\ ABSTRACT}

Adsorption and desorption isotherms for two different varieties of peanuts, namely: Ismailial "Is1" and Giza5 "G5" were evaluated using the dynamic method of equilibrium moisture content "EMC". Three different temperatures of the circulated air " $T$ ": 30,36 and $43{ }^{\circ} C$; four different levels of relative humidity " $R H$ " namely: 2.5, 32, 46 and $87 \%$ were studied. Non-linear regression analysis was made for evaluating the compatibility of the experimental data to Henderson's model.

Multiple regression analysis was also used to sensitize a generalized model and for determining the effect of peanut variety, adjacent air temperature and relative humidity on the EMC of peanut for both adsorption and desorption tests for the previously defined range of both $T$ and $R H$. The main objective of the present study is to evaluate the best fit model for the equilibrium moisture content to be available in analytical study for drying, storage and practical design of drying systems of peanut.

\section{ITRODUCTION}

$\mathrm{P}$ eanut (Arachis hypogea L.) is one of the most important oil bearing seeds. In Egypt the cultivated area is about $3.024 \times 10^{6}$ ha FAO (2008), that produced about $15.12 \times 10^{6}$ tons. In the last few years there was a marked deterioration in quality of peanut grown in Egypt, due to high incidence of aflatoxin contamination and increased percentage of immature seeds.

The growth of mould on the peanut is the indirect result of too much moisture for unsafe storage .To control the fungal attack on the peanut it was recommended by Hummeida and Ismail (1989) that the moisture content of the peanuts should be maintained below $8 \%$ w.b. However, in storage the moisture content controlled by circulation of air and control

Associate Prof. , Agric. Eng. Dept. Faculty of Agric., Al-Azhar Univ.;

Lect. Agric. Eng. Dept. Faculty of Agric., Al-Azhar Univ. 
of the relative humidity. Hall (1980) mentioned two different methods for determining the EMC:

1. Static method, in which atmosphere surrounding the product comes to equilibrium with the product without mechanical agitation of air or product.

2. The dynamic method, in which the atmosphere surrounding the product itself is mechanically moved.

He preferred the static method than the dynamic one. Although, the dynamic method is quicker but represents problems in design and instrumentations. Therefore, the static method has been used extensively. Several weeks may be required using static method, whereas, with dynamic method the data may be obtained in couple of days or less. $\mathrm{He}$ also stated that when using static method for determining the EMC, saturated salt solutions or acids may be used for maintaining the desired relative humidity at the temperature of storage.

Ghanem (1998) used a device especially constructed for EMC determination of the animal manure. The device consists of 4-units to have four different concentrations of the $\mathrm{H}_{2} \mathrm{SO}_{4}$ acid solution, i.e., four different relative humidities, each of them containing two flasks, air diaphragm pump, sample holder and a large container including the sample and the air pump i.e., (closed circulation of air).

Ghanem and El- Soaly (1999) modified the device used by Ghanem (1998) adding two flasks for acid solution , two empty flasks (condensers) and an air filter per each unit for eliminating any doubts that acid vapor could reach to the sample holder.

Tagwa et al. (1993) used the static method for the determination of the equilibrium moisture content of the buckwheat. The EMC of buckwheat in desorption was measured suspending $10 \mathrm{~g}$ of sample in 10 liter wide mouth bottle with saturated salt solution to maintain a constant humidity $( \pm 0.04 \%)$ at constant temperature $\left( \pm 1^{0} \mathrm{C}\right)$. They added that the sample was removed for weighing at intervals of two or three days. They also added that, the EMC reached when the sample mass did not change 0.01 mg (or less) in its weight over a period of two or thee days. 
Hummeida and Ismail (1989) determined the EMC of MH383 and Barberton varieties of peanut. They reported that the relative humidity has a pronounced effect on variability of EMC than the temperature.

Chen and Morey (1989) found that no universal equation could be established to fit all isotherms. The modified Henderson and Chung Pfost equations are satisfactory models for most starchy grains and fibrous materials.

Chen (2000) reported that the modified Henderson and Chung- Pfost equations had fairly high values of the deviations and standard error ,thereby, making the equations inadequate.

The main objective of the present study is to evaluate the best fit model for the equilibrium moisture content to be available in analytical study for drying, storage and practical design for drying systems of peanut.

\section{MATERIALS AND METHODS}

In this work, the device used by Ghanem (1998) and Ghanem and ElSoaly (1999) is modified by adding two condensers with gravel stones and two air fillets to each unit for eliminating any doubts that the acid vapor could not reach to the sample holder. Fig (1) shows the one unit of the experimental setup used for for controlling air temperature and relative humidity.

\section{Measuring instrumentations:}

1- Glass thermometer: for measuring the dry bulb temperatures. Source of manufacture: China, range:1-100 .

2- Thermocouples : Temperatures were measured using Type K thermocouples, the output device includes a large 4-digits temperature reading display and electronic circuitry, the specifications of thermocouples are :

Manufacture : U.S.A,

Model : $\quad 8528-40$

Full accuracy : $18-28^{\circ} \mathrm{C}$,

Useful range $: 4-45^{\circ} \mathrm{C}$.

3- Relative humidity: Is measured by hygrometers $1-100 \%$, made in Germany.

4- Electrical balance: made in Japan, Sartorius type, accuracy $0.0001 \mathrm{~g}$. 
5- The EMC for peanut pods (shells and kernels) is evaluated according to the ASAE standards (1994) i.e., oven dried at $130{ }^{\circ} \mathrm{C}$ for 6 hours.

Fig. (1) shows the one unit of the experimental setup used for for controlling air temperature and relative humidity.

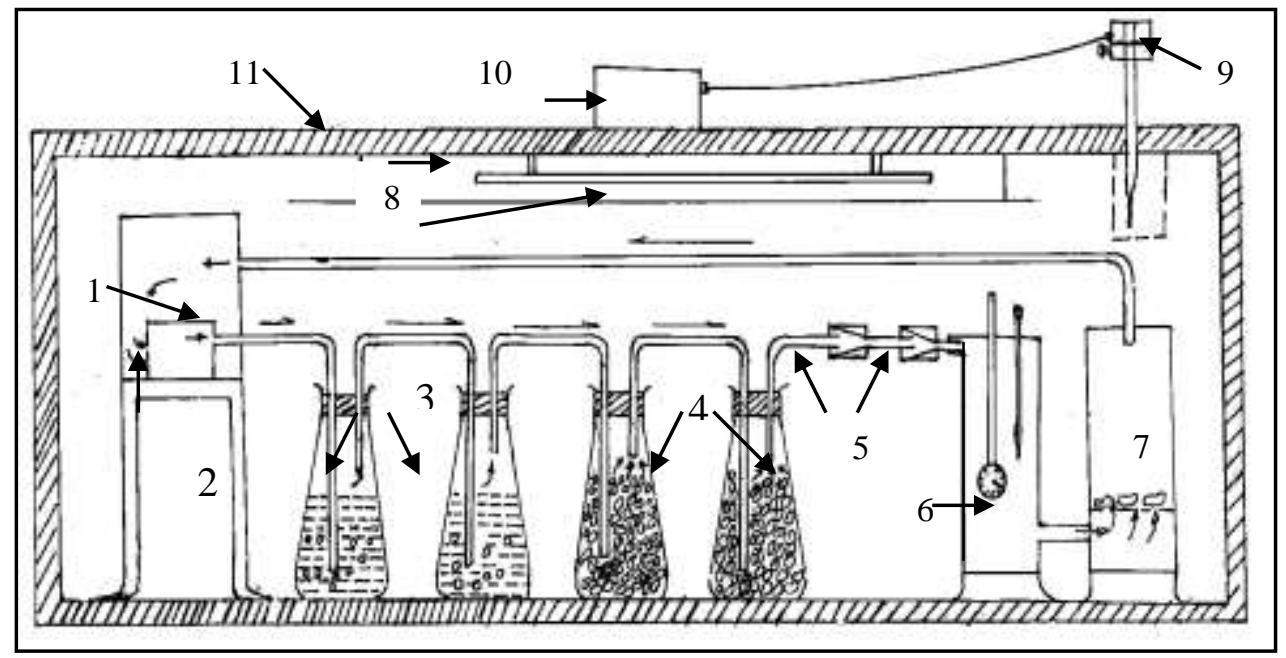

1- Diaphragm pump container

2 - Diaphragm pump

3 - Acid solution flasks

4 - Flasks with gravel stones "condensers"

5 - Air filters
6 - Hygrometer and thermometer container

7- Sample holder

8 - Air heater and its shield

9 - Glass thermometer

10 - Contactor

11 - Insulation

Fig. (1) The experimental setup for controlling air temperature and relative humidity

\section{METHODS}

To undergo the adsorption tests, peanuts were dried to low moisture content of $2 \% \mathrm{db}$. The pods were oven dried at $40{ }^{\circ} \mathrm{C}$. Weight readings were taken at intervals of $24 \mathrm{~h}$. It took about 4-5 days for the various samples of the two varieties to dry to $2 \% \mathrm{db}$. Six different experiments were carried out for each peanut variety to determine the adsorption and 
desorption EMC at four different relative humidities and three different air temperatures.

Non-linear regression analysis was made for evaluating the compatibility of the experimental data to Henderson's model as reported by Hall (1980).

Multiple regression analysis was also used to sensitize a generalized model and for determining the effect of peanut variety, adjacent air temperature and relative humidity on the EMC of peanut for both adsorption and desorption tests.

\section{RESULTS AND DISCUSSIONS}

The measured data of the three peanut isotherms $\left(30,36\right.$ and $\left.43{ }^{\circ} \mathrm{C}\right)$ for both adsorption and desorption EMC are presented on a plot for each variety tested. The effects of each of the temperature and relative humidity on the EMC was analyzed using regression analysis by Minitab 12 for statistical analysis.

Effect of relative humidity: In an effort to study the effect of the relative humidity on the equilibrium moisture content - at constant temperatureof the two varieties tested for both adsorption and desorption experiments, regression analysis was made and the following linear equation form was found to be satisfied:

$$
\mathrm{EMC}=\mathrm{a}+\mathrm{m} \text { RH }
$$

Where "a" and " $\mathrm{m}$ " are constants whose values are depicted in Table (1). This form is valid for relative humidity range of 2.5 to $87 \%$ and temperature range of 30 to $43{ }^{\circ} \mathrm{C}$. The relative humidity is expressed in decimal and the EMC is expressed in \% dry basis.

The regression coefficients of those equations show that the EMC is expected to increase by 0.111 to 0.138 when the $\mathrm{RH}$ increased by $1 \%$. Regressing the EMC data on the RH for each isotherm using exponential form, it was found that the best fit equations have coefficients of determination ranging between 0.93 to 0.99 which are more satisfactorily than that of linear equations.

Figs 2 to 5 show the experimental data for the adsorption and desorption isotherms of the two varieties tested.

The following equation form was found to be satisfied:

$$
\mathrm{EMC}=\mathrm{Ae}^{\alpha \mathrm{RH}}
$$

Misr J. Ag. Eng., April 2009 
Where "A" and " $\alpha$ " are constants as given in Figs. 2 to 5 .

\section{Effect of temperature :}

Figs. 2 to 5 show that isotherms of high temperatures lie underneath low ones. It can be generally stated that there is an inverse relationship between the EMC and the temperature of the circulated air. Table (1) shows also the regression coefficients and coefficients of determinations of the EMC and the air temperature at constant relative humidity of the air. The coefficients of determination were very low and ranged between 0.0509 to 0.522 .

Table (1) Regression coefficients and coefficients of determination for peanut experiments using linear form.

\begin{tabular}{|l|c|c|c|c|c|c|}
\hline Effect of & Variety & Ads./Des. & $\mathrm{a}, \mathrm{a}_{1}$ & $\mathrm{~m}, \mathrm{~m}_{1}$ & $\mathrm{~d}$ & $\mathrm{R}^{2}$ \\
\hline \multirow{4}{*}{$\begin{array}{l}\text { Relative } \\
\text { humidity }\end{array}$} & $\mathrm{IS} 1$ & Ads. & 1.6840 & 0.111 & - & 0.8800 \\
\cline { 2 - 7 } & $\mathrm{IS} 1$ & Des. & 2.7190 & 0.116 & - & 0.9080 \\
\cline { 2 - 7 } & $\mathrm{G} 5$ & Ads. & 1.6200 & 0.114 & - & 0.8700 \\
\cline { 2 - 7 } & $\mathrm{G} 5$ & Des. & 2.0200 & 0.138 & - & 0.9100 \\
\hline \multirow{4}{*}{ Temperature } & $\mathrm{IS} 1$ & Ads. & 48.644 & 2.136 & - & 0.0840 \\
\cline { 2 - 7 } & $\mathrm{IS} 1$ & Des. & 50.460 & 2.690 & - & 0.1591 \\
\cline { 2 - 7 } & $\mathrm{G} 5$ & Ads. & 45.032 & 1.634 & - & 0.0509 \\
\cline { 2 - 7 } & $\mathrm{G} 5$ & Des. & 20.085 & 3.240 & - & 0.5220 \\
\hline \multirow{3}{*}{$\begin{array}{l}\text { Relative } \\
\text { humidity } \\
\text { and } \\
\text { temperature }\end{array}$} & $\mathrm{IS} 1$ & Ads. & 16.300 & 0.0630 & 0.4530 & 0.907 \\
\cline { 2 - 7 } & $\mathrm{IS} 1$ & Des. & 19.700 & 0.0853 & 0.0577 & 0.875 \\
\cline { 2 - 7 } & $\mathrm{G} 5$ & Ads. & 19.400 & 0.0853 & 0.0563 & 0.870 \\
\hline
\end{tabular}




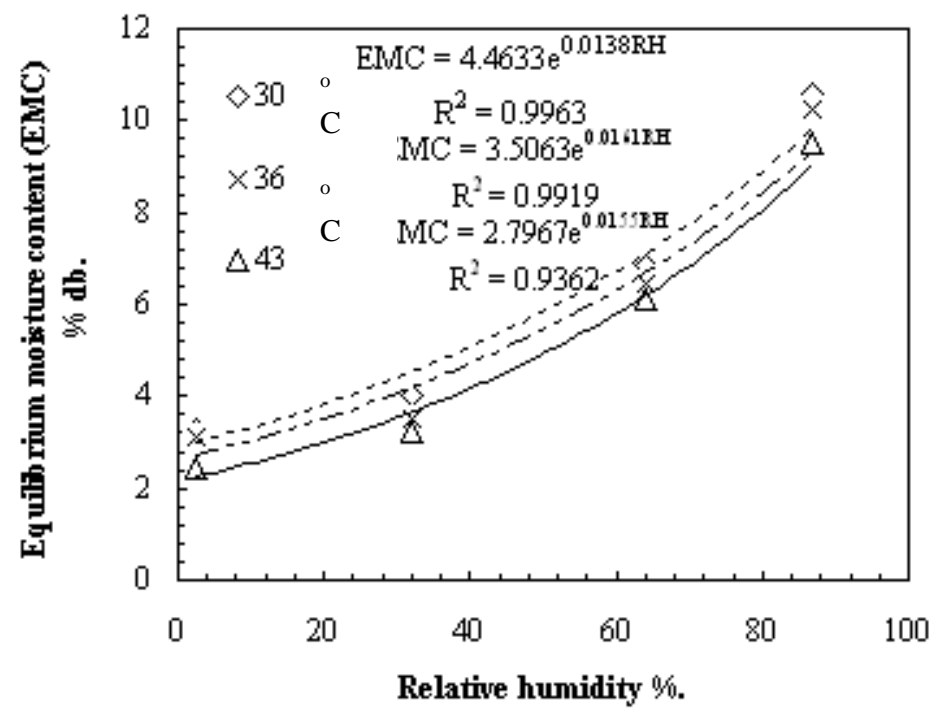

Fig (2) Desorption isotherms for Isl variety at three different tenperatures.

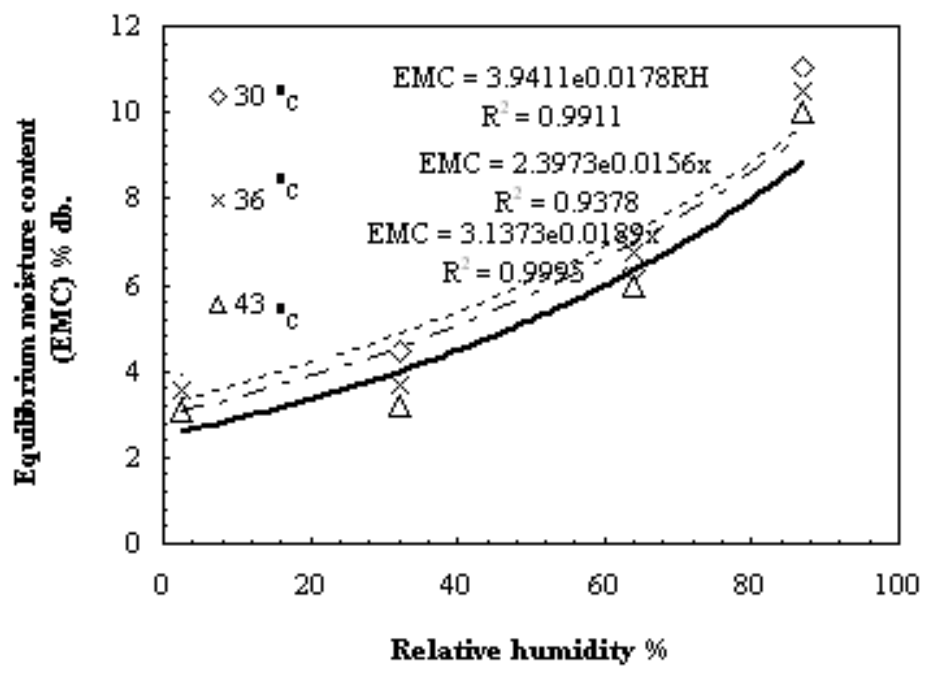

Fig(3) Desorption isotherms for G5 variety at three different temperatures. 


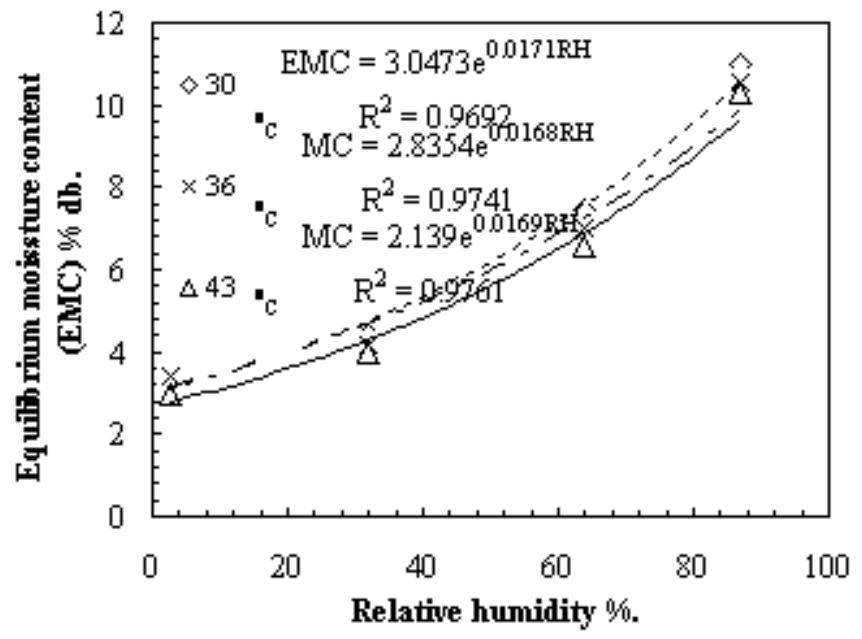

Fig (4) Adsorption isotherms for Isl variety at three different temperatures .

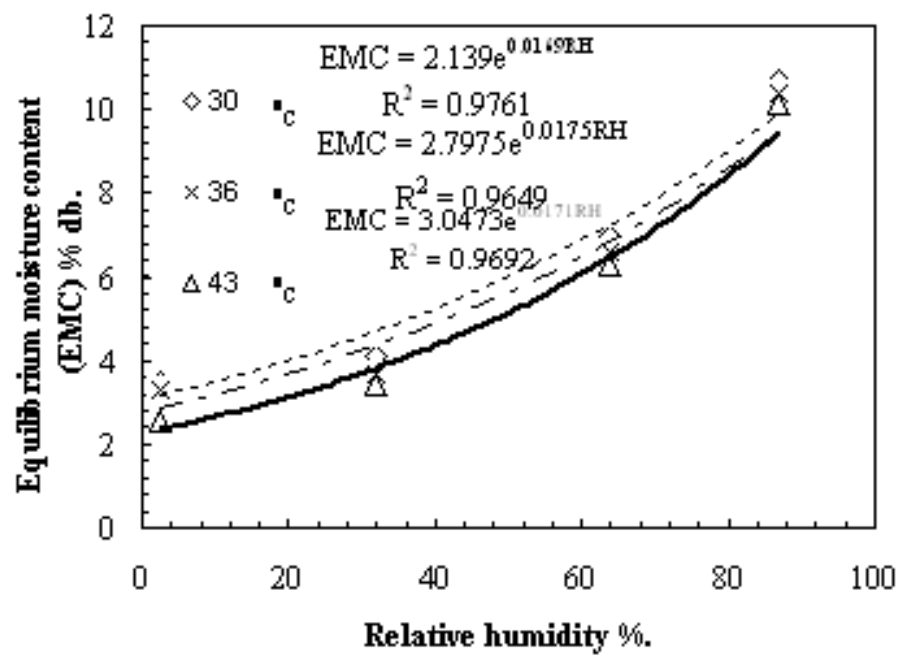

Fig (5) Adsorption isotherms for G5 variety at three different temperatures 


\section{Compatibility of the experimental data to Henderson's model}

Non-linear regression analysis was made for evaluating Henderson's equation (Hall 1980) parameters on adsorption and desorption experiments for both varieties tested. The Henderson's model is of the form :

$$
1-\mathrm{RH}=e^{-c T(E M C)^{n}}
$$

For determining the constants "c" and " $\mathrm{n}$ ", transformation was made and $\ln (\mathrm{EMC})$ was plotted against $\ln (\ln (1-\mathrm{RH}) / \mathrm{T})$. Table (2) shows the values of "c" and " $\mathrm{n}$ " parameters, coefficients of determination, standard deviation and the standard error for adsorption and adsorption experiments for both varieties tested.

The coefficient of determination was low and has values ranging between 0.4164 and 0.584 for all experiments. The Henderson's model has fairly high values of deviation and standard error as depicted in Table (2) and, thereby, making the equation inadequate. This result agrees with Chen (2000).

\section{Combined effect of the relative humidity and absolute air temperature on the EMC:}

The combined effect of the relative humidity ranging between 2.5 to $87 \%$ and absolute air temperature "Tabs" ranging between 303 to $316{ }^{\circ} \mathrm{K}$ on the EMC was investigated. Multiple regression analysis was conducted and the following model was found to be satisfied :

$\mathrm{EMC}=\mathrm{a}_{1}+\mathrm{m}_{1} \mathrm{RH}-\mathrm{d}$ Tabs

Table (1) includes values of $\mathrm{a}_{1}, \mathrm{~m}_{1}$ and $\mathrm{d}$ for both adsorption and desorption experiments and the two varieties tested. Table (3)shows that the coefficient, of determination of the relationship between relative humidity and EMC are 0.924, 0.895 and 0.898, 0.879 for the adsorption and desorption experiments for the Is1 and G5 varieties respectively.

Adding the absolute temperature to the model reduced the coefficients of determination to $0.907,0.872$ and $0.875,0.853$ for the adsorption and desorption experiments of the Is 1 and G5 varieties respectively, as depicted in Table (3).

The partial effect of the relative humidity on the EMC was evaluated using the partial correlation coefficients which are $0.88,0.87$ and $0.87,0.84$ of the Misr J. Ag. Eng., April 2009 
adsorption and desorption experiments for Is1 and G5 varieties respectively as depicted in Table (4). The partial effect of the absolute temperature on the EMC was also evaluated. It was found that the values of partial correlation coefficients were decreased to $0.15,0.20$ and $0.21,0.20$ of the adsorption and desorption experiments for Is 1 and G5 varieties respectively as depicted in Table (4).

\section{Variety effect}

Figs 6 to 7 show the variety effect for both desorption and adsorption tests. It is clear that the variety effect on the variability of the EMC was found to be minor, ranging between 0.04 to $0.62 \% \mathrm{db}$. This means that the EMC data of one variety can be used for the other without significant error.

Table(2) Non-linear regression analysis for determining the compatibility of experimental data to Henderson's model.

\begin{tabular}{|l|c|c|c|c|c|c|}
\hline $\begin{array}{l}\text { Peanut } \\
\text { variety }\end{array}$ & Ads./Des. & $\mathrm{C}$ & $\mathrm{n}$ & $\mathrm{R}^{2}$ & $\begin{array}{c}\text { Standard } \\
\text { deviation }\end{array}$ & $\begin{array}{c}\text { Standard } \\
\text { error }\end{array}$ \\
\hline \multirow{2}{*}{ IS1 } & Ads. & 7.2418 & 1.2418 & 0.5138 & 0.4700 & 9.61 \\
\cline { 2 - 7 } & Des. & 7.7516 & 1.6378 & 0.5841 & 0.5522 & 8.57 \\
\hline \multirow{2}{*}{ G5 } & Ads. & 7.2886 & 1.4023 & 0.4164 & 0.5469 & 8.49 \\
\cline { 2 - 7 } & Des. & 7.4230 & 1.4521 & 0.5065 & 0.5220 & 8.57 \\
\hline
\end{tabular}

Table (3) Coefficients of determination between EMC, RH and EMC,RH,Tabs for the multiple regression analysis .

\begin{tabular}{|l|c|c|c|c|c|}
\hline \multirow{3}{*}{$\begin{array}{l}\text { Peanut } \\
\text { variety }\end{array}$} & \multicolumn{3}{|c|}{ Coefficients of determination } & \multicolumn{2}{c|}{$\begin{array}{c}\text { Standard deviation } \\
\text { with }\end{array}$} \\
\cline { 2 - 6 } & Ads./Des & $\begin{array}{c}\text { EMC } \\
\text { \& RH }\end{array}$ & EMC\&RH\&Tabs & RH\% & Tabs \\
\hline \multirow{2}{*}{ IS1 } & Ads. & 0.924 & 0.907 & 0.008271 & 0.0498 \\
\cline { 2 - 6 } & Des. & 0.898 & 0.875 & 0.009640 & 0.0580 \\
\hline \multirow{2}{*}{ G5 } & Ads. & 0.895 & 0.872 & 0.00978 & 0.0589 \\
\cline { 2 - 6 } & Des. & 0.879 & 0.853 & 0.01060 & 0.0638 \\
\hline
\end{tabular}

Table (4) Partial correlation coefficients of EMC,RH and EMC, \& Tabs.

\begin{tabular}{|l|c|c|c|}
\hline Peanut variety & Ads./Des & EMC \& RH & EMC \& Tabs \\
\hline IS1 & Ads. & 0.88 & 0.15 \\
\cline { 2 - 4 } & Des. & 0.87 & 0.21 \\
\hline \multirow{2}{*}{ G5 } & Ads. & 0.87 & 0.20 \\
\cline { 2 - 4 } & Des. & 0.84 & 0.20 \\
\hline
\end{tabular}

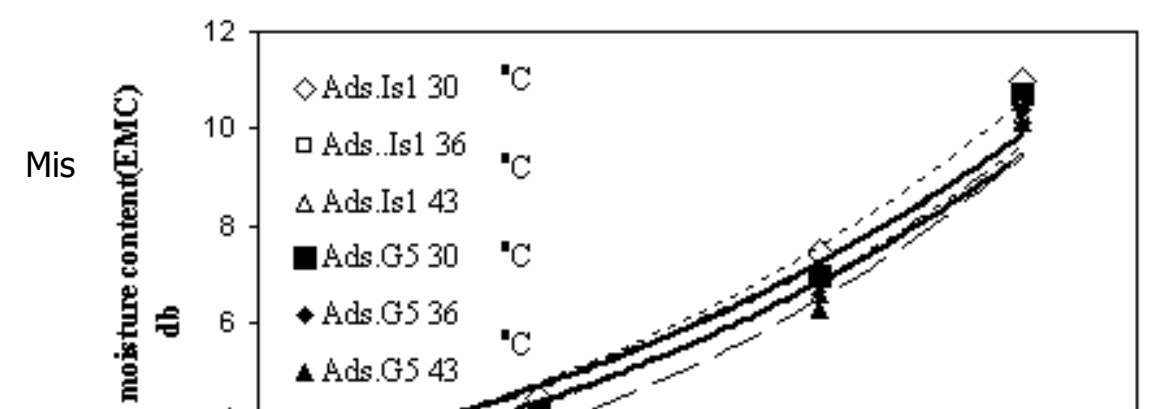




\section{SUMMARY AND CONCLUSION}

Misr J. Ag. Eng., April 2009 
In the present study adsorption and desorption moisture contents of Ismalia1 and Giza5 varieties of peanut were evaluated using the dynamic method. Six different experiments were carried out for each peanut variety to determine the adsorption and desorption EMC at four different relative humidities: 2.5 32, 64and $87 \%$ and three different air temperatures 30,36 and $43{ }^{\circ} \mathrm{C}$.

Regression analysis was made for the experimental data, it was found that:

1- The exponential model is satisfied for the relationship between the equilibrium moisture content and the relative humidity with coefficient of determination ranging between 0.93-0.99.

2- Non linear regression analysis was made for evaluating the compatibility of the experimental data to Henderson's model as reported by Hall (1980). It was found that the Henderson's model has fairly high values of deviation and standard error, Thereby, making the model inadequate.

3- The relative humidity "RH" has more pronounced effect on the variability of the equilibrium moisture content "EMC" than the absolute air temperature"Tabs". Multiple regression analysis was conducted and the following model was found to be satisfied:

$$
\mathrm{EMC}=\mathrm{a}_{1}+\mathrm{m}_{1} \mathrm{RH}-\mathrm{d} \text { Tabs }
$$

$$
\text { ( } \mathrm{R}^{2} \text { range } 0.90-0.872 \text { ) }
$$

Where $\mathrm{a}_{1}, \mathrm{~m}_{1}$ and $\mathrm{d}$ are constants .

4- The partial correlation coefficients between the equilibrium moisture content and the relative humidity ranged between 0.88 0.84 , whereas, they ranged between $0.15-0.21$ for the equilibrium moisture content and the absolute temperature relationships.

5- The variety of peanut is found to have little effect on the variability of the equilibrium moisture content $(0.04-0.62 \%$ d.b.). This means that the equilibrium moisture content data of one variety can be used for other without significant error.

\section{REFFRENCES}


ASAE 1994.Moisture measurement-peanut .Agric. Eng. Yearbook 5410Dec92St. Joseph Michigan, :477-478.

Chen C. and R.V. morey 1989. Comparison of four EMC/RH Equations. Trans. Of theASAE.32(3):983-990.

Chen C. 2000. A rapid method to determine the sorption isotherms of peanut. J. Agric. Eng. Res. (75) :401-408.

FAO2008.Cultivated area of agric. crops. www. org./docrep/v9998e/ v9998 Oe.htm. at 12/10/2008.

Ghanem T.H. 1998. Solar energy utilization, specifically on drying or sterilization of animal manure under Egyptian conditions for use as protein supplement in animal feed.Ph.D. Thesis Fac. of Agric. Eng. Dept. Al-Azhar U.: 95-99.

Ghanem T.H. and I..S. El-Soaly 1999.Desorptoin equilibrium moisture content relationship for okra as affected by ambient air temperature and relative humidity. The $7^{\text {th }}$ conf.Misr Soc. of Agric.Eng.,27-28 Oct.: 50-59.

Hall,C.W. 1980.Drying and storage of agricultural crops. The AVI Pub. Inc. Westport Conn. U.S.A:921-308.

Hummeida M.A. and M.A.Ismail1989.Determination of equilibrium moisture content for two varieties of peanut. Agric. Mech. Asia and Latin America. 20(3): 53-58.

Tgwa A., Murata S. and Hayashi, 1993. Latent heat of vaporization in buckwheat using the data of equilibrium moisture content. Trans. ASAE 36(10:113-114.

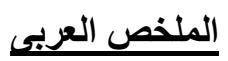




\section{المحتوى الرطوبى التعادلى لصنفين من الفول السودانى}

د/ طارق حسين غانم د/محمد احمد السيد شيتيوى د/ سمير حافظ محمد دسوقى

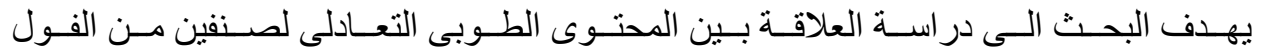

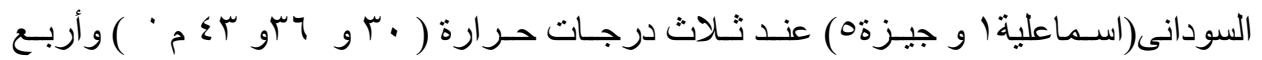

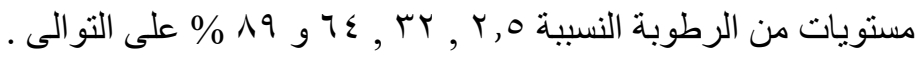
و بإِتخدام الإِحدار تم التوصل الى الآتى:

ا ـ تمثل المعادلة الأسية العلاقة بين المحتوى الرطوبى التعادلى و الرطوبة النسبية بدرجـة عاليـة،

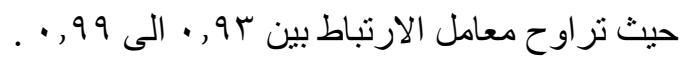

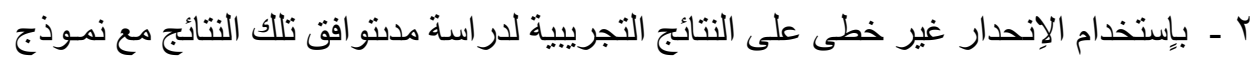

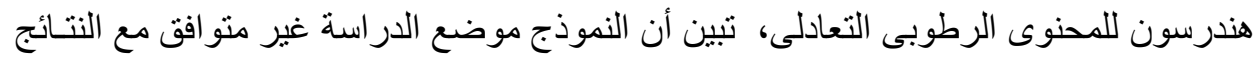

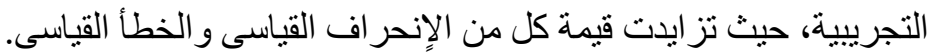
rـ ان الرطوبة النسبية لها تأثير واضح على تغير المحتوى الرطوبى التعادلى مقارنتاً بتاثير تنغير

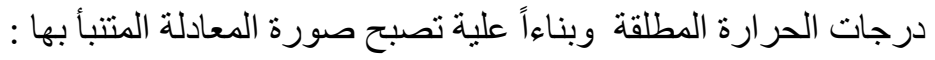
$\mathrm{EMC}=\mathrm{a}_{1}+\mathrm{m}_{1} \mathrm{RH}-\mathrm{d}$ Tabs

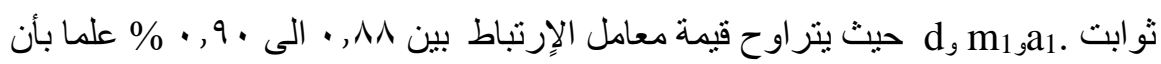

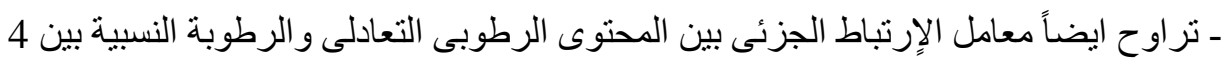

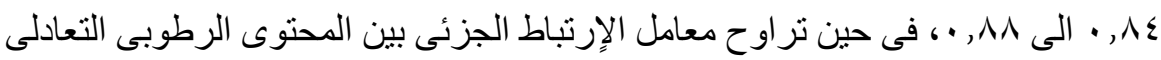
ودرجة الحر ارة المطلقة بين 10 , • الى البر , • مما يؤكد ان الرطوبة النسبية هى العامل المتفوق

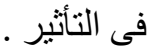

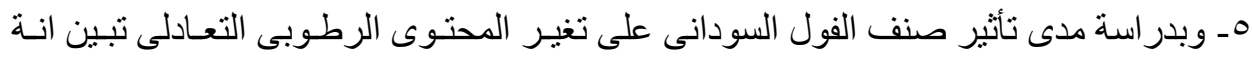

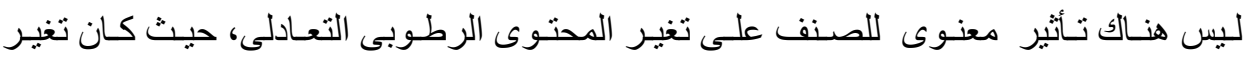

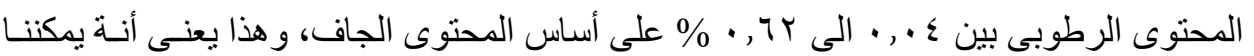

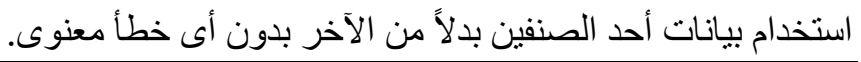

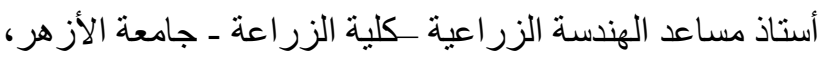
مدرس الهندسة الزر اعية ـكلية الزراعة الزية ـ جامعة الأز هر. 